\title{
THE ROLE OF THE DIGITAL COMPETENCE OF EMPLOYEES IN THE MARKETING MANAGEMENT OF AGRICULTURAL ENTERPRISES
}

T. BALANOVSKA, PhD in Economics, Professor, Professor of the Department of Management named after Prof. J.S. Zavadskyi

National University of Life and Environmental Sciences of Ukraine ORCID 0000-0001-6814-5888

E-mail: balanovskaya@nubip.edu.ua

\author{
B. WYRZYKOWSKA, PhD in Economics, Assistant Professor \\ of Management Institute \\ Warsaw University of Life Sciences (SGGW) \\ ORCID 0000-0002-7025-0799 \\ E-mail: barbara_wyrzykowska@sggw.edu.pl \\ V. VOSKOLUPOV, PhD student \\ National University of Life and Environmental Sciences of Ukraine \\ ORCID 0000-0003-1924-6310 \\ E-mail:voskolupov@gmail.com
}

\begin{abstract}
The article reveals the role of the digital competence of employees in the marketing management of agricultural enterprises. It has been noted that marketing management is one of the novel approaches to managing an agricultural enterprise. It has been found that the successful all-levels marketing management of agricultural enterprises essentially depends on the holistic development of employees, so it is crucial to devote attention to professional knowledge of specialists, their ability to respond swiftly to market demands, ability to communicate, assume responsibility for performance results, as well as be engaged in life-long learning. It has been noted that cutting-edge technologies and equipment demand from employees to be digitally competent.

The essence of digital competence has been revealed. The key components of the application of digital competence by agricultural commodity producers, which are crucial when looking for buyers and suppliers, or studying the market, have been considered. Since the state-of-the-art digital technologies require an Internet connection, the possibility of the rural population of Ukraine to have access to the Internet has been analyzed. It has been noted that the formation and development of the digital competence of employees constitutes an integral part of marketing management in agricultural enterprises thus improving the knowledge and skills of personnel when making managerial decisions, and providing competitive strengths and justification of enterprise development strategy.
\end{abstract}

Keywords: marketing, marketing management, digital competence, marketing research, agricultural enterprise. 
Introduction. A dynamic environment provides every enterprise with both huge opportunities and threats due to the rising levels of uncertainty and risks. To ensure the successful operation of agricultural enterprises under such conditions it is necessary to find brand new approaches to manage their activities, and marketing management is one of these approaches.

In today's world, information technologies are rapidly developing, various devices are constantly appearing, and the number of Internet users is growing. Most specializations and professions - and especially marketing management - require understanding and application of information and digital technologies. It is crucial for employees to be digitally competent because it involves mastering the knowledge and skills necessary for effective and safe existence in a volatile digital space, including the ability to receive, process, use the relevant information, and be perfect in modern digital technologies.

Analysis of recent research and publications. Ukrainian and foreign scientists such as L. Balabanova, O. Bilovodska, A. Voichak, I. Komarnytskyi, F. Kotler, V. Kutsenko, M. Porter, V. Rossokha and others devoted much attention to the issues of marketing management in their papers. Many scientists in various fields, including M. Vedernikov, L. Dovhan, V. Kuibida, S. Leiko, A. Oleshko, A. Synychenko, L. Fedulova and others, studied the issue of digital competence of employees. Scientific researches are crucial for theory and practice, but the issue of the formation and development of digital competence of employees as a key component of successful marketing management in agricultural enterprises requires further study.

The purpose of the research is to reveal the role of the digital competence of specialists in the marketing management of agricultural enterprises of Ukraine.

Materials and methods. In the course of the research, a dialectic method and generally scientific methods such as analysis, synthesis, comparison and generalization were used for collecting, analyzing, information assessing and conclusions making. 
Results of research and discussion. Marketing management is one of the novel approaches to managing an agricultural enterprise. It involves achieving the target, constant growth of the enterprise, maintaining and mastering new competitive strengths, taking on the market and successful functioning in unstable conditions.

Having summarized the scientific opinions $[2,4,7,12,14,22]$ on the essence of marketing management, it is possible to say that it is the management of all functions and structural units with the help of marketing. Bilovodska O.A. [4] emphasizes that marketing management is a change of thinking - making all managerial decisions taking into account market requirements, the constant ability to change market requirements meaning that the organization should take into account both internal capabilities and external conditions. We agree with the statement of Raiko D.V. and Lebedeva L.E. [22] that marketing management is a brand new approach, firstly, to the strategic management of the organization, which is based on the market orientation in a highly competitive environment.

Marketing management is one of the novel approaches to managing an agricultural enterprise. It involves achieving the target, constant growth of the enterprise, maintaining and mastering new competitive strengths, taking on the market and successful functioning in unstable conditions. To introduce marketing management, it is necessary to not only change the tools, techniques and methods of management but also fundamentally reorganize the existing management system, review the internal relationships between functional units and ensure a kind of interaction between them.

The successful all-levels marketing management of agricultural enterprise essentially depends on the holistic development of employees, so it is crucial to devote attention to professional knowledge of specialists, their ability to respond swiftly to market demands, ability to communicate, assume responsibility for performance results, as well as be engaged in life-long learning. The cutting-edge technologies and equipment demand from employees to be digitally competent.

Domestic and foreign scientific sources $[3,6,15,16,18,24,27,31]$ define the term 'competence' in more than one way. Competence is often understood as a 
quality, a trait of a person making it possible for that person (or even giving the right) to overcome certain issues, make decisions and judgments in a particular field. This quality is based on knowledge, awareness, and experience of social and professional activities [6]. Ana B. Mirete stated that competence is the ability to select and mobilize knowledge, skills and attitudes to respond successfully to a given professional situation [31]. The National Framework of Qualifications, approved by the Resolution of the Cabinet of Ministers of Ukraine as of November 23, 2011 No 1341, defines 'competence as a dynamic combination of knowledge, skills, abilities, ways of thinking, views, values, other personal traits determining a person`s ability to successfully socialize, work and/or study' [20].

On 17 January 2018, an updated version of the key competences for life-long learning was approved - Recommendation 2018/0008 (NLE) of the European Parliament and the Council (EU): Literacy competence; Languages competence; Mathematical competence and competence in science, technology and engineering; Digital competence; Personal, social and learning competence; Civic competence; Entrepreneurship competence; Cultural awareness and expression competence [11; 29]. Following the Recommendations, 'digital competence includes the confident, critical and responsible use and interaction with digital technologies for learning, work and social life. It includes information literacy and data literacy, communication and collaboration, digital content creation (including programming), security (including digital well-being and cybersecurity competencies), and problem-solving' $[11 ; 29]$.

The digital competence of employees is crucial for marketing management, in particular when looking for buyers and suppliers or studying the market. The above can be done using information resources of global networks, optimization tools, automated information systems of an enterprise, tooling and applications for statistical and econometric analysis, free software, Internet services, and mobile apps. The components of the application of digital competence by agricultural commodity producers are given in Fig. 1. 


\begin{tabular}{|c|}
\hline Components of the application of digital competence \\
\hline $\begin{array}{l}\text { Software (spreadsheet and graphic editors, web browsers, search engines, electronic } \\
\text { social media, etc.) }\end{array}$ \\
\hline Internet access (highlighted line - xDSL, GPRS, 3G, LTE, WiFi) \\
\hline Special-purpose websites for agricultural commodity producers \\
\hline $\begin{array}{l}\text { Information portal of agroidustrial complex of Ukraine (news, conferences, grants, } \\
\text { consulting services) }\end{array}$ \\
\hline $\begin{array}{l}\text { National Association of Agricultural Advisory Services of Ukraine (NAAASU) } \\
\text { (remote training, information support, business planning and engineering) }\end{array}$ \\
\hline $\begin{array}{l}\text { Association of farmers and private landowners of Ukraine (protection of farmers } \\
\text { rights, legislative amendments, press conferences, meetings of a joint task force with } \\
\text { government officials, meetings with top public officials, public gatherings) }\end{array}$ \\
\hline $\begin{array}{c}\text { Websites of consulting companies (consulting, audit, asset management, } \\
\text { agribusiness establishment on a turnkey basis) }\end{array}$ \\
\hline Mobile apps \\
\hline AgroPoint (price base, search for partners, suppliers, customers) \\
\hline $\begin{array}{c}\text { AgroUA (news, prices for agricultural products, publication of purchase/sale offers, } \\
\text { Push notifications in case of raider attacks) }\end{array}$ \\
\hline
\end{tabular}

\section{Fig. 1. Components of the application of digital competence by agricultural commodity producers}

Today, the ability to work with general and special-purpose software for solving a wide range of marketing issues, which involves the use of text, spreadsheet, and graphic editors (WordPad, MS Word, OpenOffice, MS Excel, Adobe Photoshop, MS Picture Manager, MS PowerPoint), Web browsers (Google Chrome, Safari, Internet Explorer and Edge, Mozilla Firefox, Opera), search engines (Google, Yahoo, Bing, Baidu), electronic social media (Facebook, Instagram, Twiter), cloud storage (Dropbox, Google Drive, OneDrive, iCloud), database management systems, network applications, etc. shows that the employee is digitally competent Large agricultural enterprises will benefit from the use of a professional program called Marketing Analytic. This is a full-featured system designed to solve issues arising in the course 
of marketing activity recording (including sales record), marketing analysis, including the processing of marketing research results (external and internal factors), as well as in the course of developing strategic and operational marketing plans, which assists in construction and control of marketing budgets (sales and business expenses budget) [30]. Computer literacy is the basis of the digital competence of a specialist, a key component of his/her competitiveness in the modern labor market.

In order for an agricultural enterprise to use marketing management tools through modern services and websites, an employee should have an appropriate level of digital competence. For instance, Google Alerts detects the selected products online, including agricultural products, and sends emails with the found options. Google Trends is one of the most promising services for marketing research as it shows what people are searching for right now, determines the number of users searching for a particular product, illustrates the current demand.

Having analyzed the information sources of websites of state institutions of Ukraine (ministries, departments, state regional administrations), it can be noted that one of the important websites that contains a lot of useful information for the development of agricultural enterprises is 'Information portal of agro industrial complex of Ukraine' [10]. There you can find the recent news in the agricultural sector of Ukraine`s economy, the dates of conferences, the existing grants and how to get them, and other consulting services. For 2020 Ukraine prepared a number of options to support agricultural commodity producers, including financial injection for the development of farms; financial injection on condition of repayment (interest-free loans) through the Ukrainian State Fund for Support of Farmers; government support through surcharges in favor of insured persons - members/heads of family farms; government support for the development of animal husbandry and agricultural products processing; financial injection for the development of horticulture, viticulture and hop growing; partial reimbursement of the cost of agricultural machinery and domestically produced equipment; affordable loans 5, 7, 9\% [10].

In addition to the websites of state institutions, agricultural enterprises of Ukraine may found information on the websites of agricultural associations and 
independent public associations. For instance, on the website of the National Association of Agricultural Advisory Services of Ukraine (NAAASU) you may find information on remote training and receive information support on innovational economic technologies, agricultural production, business planning and innovation engineering, development of marketing strategies, and diversification of core activities [8]. On the website of the Association of Farmers and Private Landowners of Ukraine, you may find up-to-date information on the protection of farmers` rights, legislative amendments, press conferences, applications to the Verkhovna Rada of Ukraine, the Cabinet of Ministers of Ukraine, executive authorities, local governments, meetings of a joint task force with government officials, meetings with top public officials, public gatherings, farmers`campaigns [1].

It should be emphasized that agricultural enterprises may find information and receive consulting services from private consulting companies that sell machinery, equipment, agrochemicals and other agricultural products. For instance, Agro Consulting Group is a full-cycle agricultural producer (grain and oilseeds - corn, soybeans, wheat, sunflower), which audits and manages agricultural assets [13]. There are also consulting companies offering turnkey services for agribusiness in Ukraine. For instance, Agricultural Consulting Service carries out technical audits of agribusiness, agricultural projects, and farms on a turnkey basis, as well as provides consulting services [28]. However, these organizations are focused on the promotion of a specific (own) product or cooperation with large enterprises in certain product industries. Advisory Services provide a much wider range of services, focusing on the application of developments of various domestic and foreign producers. They help agricultural commodity producers access the achievements of science and best practices.

These days a person can hardly be imagined without a mobile phone with mobile apps installed on it. Mobile apps are one of the sources of information on the Internet that becomes increasingly popular among agricultural commodity producers. Every year mobile devices strengthen their presence in the agricultural sector. For instance, according to Statista as of 2019, the number of sold smartphones in the 
world is 15 times higher than the number of sold PC [19]. But most farmers tend to use mobile phones for communication and social media, rather than for improving their skills by searching for mobile apps, better services, and websites.

Depending on the method of application in the agricultural enterprise, mobile apps can be divided into programs for internal needs and for external communications. Internal apps are used on both employees devices and enterprise devices. Agricultural mobile apps for external use are usually designed for searching business partners, markets, suppliers of raw materials, seeds, plant protection products, fertilizers, customers, etc. For instance, the mobile app AgroPoint is designed for searching agribusiness partners; it helps the user understand what kind of services they need, find partners, suppliers and customers in the agricultural sphere anywhere in the country with a single click [23]. The mobile app PROD was designed for farmers from the USAID project 'Agriculture and Rural Development Support'. This is a user-friendly app to work with the price base for vegetables and fruits throughout Ukraine. The user finds only current prices for fruits and vegetables and there is no need to visit many non-target sites. Everything is put together in one place. You can see the price of the product and find the most affordable one in a few clicks. In this app you can place your own offers for the sale of vegetables and fruits, directly communicate with the author of the offer (without intermediaries) to make a deal, receive detailed information about the cost and characteristics of the product, etc. [32]

The founders of the mobile app AgroUA promote their product as a platform for information support of agribusiness. The app can be used in more than one way; you may find news and current prices for agricultural products or place commercial and informational offers. Thanks to the AgroUA mobile app, you will stay informed about the agricultural life of the country and aware of recent events and innovative technologies. You can make your presence known to all market participants, be published in catalogs, advertise yourself and your products, and announce events or innovations. You can also announce tenders, place purchase/sale offers, communicate in the forum, follow offers and vacancies in the market, be employed, share 
experiences, follow tenders of agricultural holdings, read news, visit all agricultural Facebook groups, visit all popular agricultural sites, use guides to some agricultural events, and lots of other opportunities [17].

External agricultural mobile apps have such a useful feature as Push notification enabling quick sending of information simultaneously to all users. This message is popped up on the screens of mobile devices making it possible to cover all subscribers. Push notification is a powerful channel for transmitting information to the target audience. This service is used in the AGROSHCHIT project to help farmers in case of raider attacks - the 'raider attack' button [17]. In order for agricultural enterprises to use modern mobile apps, employees should have an appropriate level of digital competence.

The cutting-edge digital technologies may be used through the Internet connection, as it is the main source of unlimited opportunities for knowledge, skills, and abilities. However, today most agricultural workers do not have a high-quality high-speed Internet connection. According to a study by the Ministry of Digital Transformation of Ukraine, $82 \%$ of the population of Ukraine has access to highspeed 4G Internet, but if you look at the number of settlements that have Internet access, they are only $57 \%$ of the total number of settlements in the country. The agency emphasized that more than 10 thousand settlements of Ukraine, most of which are villages, still do not have access to a high-quality mobile Internet [5].

However, if we compare 2019 to 2014, the number of rural people with access to the Internet almost doubled. The number of rural people using the Internet at work remained the same, however, the number of those who use the Internet at home and anywhere via mobile phone has increased (from $18.6 \%$ in 2013 to $55.5 \%$ in 2019), IT experts forecast that the number of connected smartphones will quadruple by 2025 . At the same time, in 2019, almost half of rural households got Internet access at home. Most of them use Internet access for entertainment and communication 36$61.3 \%, 24.5 \%$ for study, and only $1.7 \%$ for interaction with public authorities and $13.3 \%$ for banking services (Table 1). 


\section{Distribution of rural population depending on the purpose of use of the Internet, \%}

\begin{tabular}{|c|c|c|c|c|c|c|c|}
\hline & 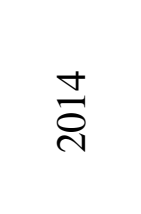 & $\frac{n}{2}$ & 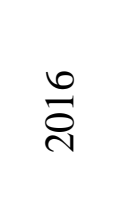 & 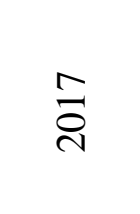 & $\stackrel{\infty}{\stackrel{\infty}{\infty}}$ & 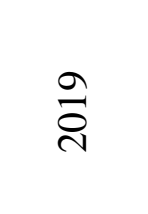 & 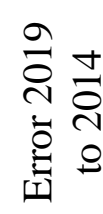 \\
\hline \multicolumn{8}{|c|}{$\begin{array}{c}\text { Distribution of population depending on the place of use of the Internet ( in \% to population that } \\
\text { claimed they used the Internet ) }\end{array}$} \\
\hline At home & 74,1 & 78,9 & 84,2 & 83,8 & 83,8 & 79,2 & 5,1 \\
\hline At work & 11.0 & 11.0 & 9,6 & 9,6 & 9,7 & 10,6 & $-0,4$ \\
\hline At the place of study & 10,9 & 10,1 & 7,6 & 7,7 & 7,1 & 7,5 & $-3,4$ \\
\hline Anywhere from the mobile phone & 17,2 & 20,2 & 20,8 & 32,8 & 46,7 & 55,5 & 38,3 \\
\hline $\begin{array}{l}\text { Other places (at friends or } \\
\text { acquaintances place) }\end{array}$ & 18,6 & 16,2 & 14,3 & 14,3 & 12,2 & 8,5 & $-10,1$ \\
\hline \multicolumn{8}{|c|}{$\begin{array}{c}\text { Distribution of population depending on the purpose of use of the Internet (in \% to population that } \\
\text { claimed they used the Internet) }\end{array}$} \\
\hline sending (receiving) e-mail & 11,8 & 18,5 & 16,9 & 15,1 & 12,9 & 17,7 & 5,9 \\
\hline interaction with public authorities & 1 & 1,6 & 1,3 & 1,5 & 1,5 & 1,7 & 0,7 \\
\hline training and education & 35,9 & 33,8 & 31,7 & 29,5 & 26,2 & 24,5 & $-11,4$ \\
\hline $\begin{array}{l}\text { reading/downloading newspapers and } \\
\text { magazines online }\end{array}$ & 24,3 & 24,7 & 24,1 & 23 & 26,6 & 17,2 & $-7,1$ \\
\hline $\begin{array}{l}\text { downloading movies, images, music; } \\
\text { watching TV, etc. }\end{array}$ & 59,8 & 56,4 & 60,7 & 63,7 & 63,8 & 61,3 & 1,5 \\
\hline $\begin{array}{l}\text { playing or downloading video or } \\
\text { computer games }\end{array}$ & 41,9 & 38,9 & 39,3 & 41,5 & 38,6 & 36 & $-5,9$ \\
\hline downloading software & 3,2 & 3,8 & 2,9 & 3,3 & 2,7 & 3,3 & 0,1 \\
\hline $\begin{array}{l}\text { telephone conversations via the } \\
\text { Internet }\end{array}$ & 31,1 & 36,8 & 38 & 41,6 & 43,8 & 39,5 & 8,4 \\
\hline communication (hobby) & 51,9 & 50,4 & 52,1 & 49,6 & 47,3 & 55,5 & 3,6 \\
\hline banking services & 2,9 & 3,9 & 6,5 & 6,6 & 8,9 & 13,3 & 10,4 \\
\hline search for information & 26,6 & 28,4 & 28,6 & 28,6 & 28,9 & 30,6 & 4 \\
\hline order (purchase) of goods & 7,9 & 11,9 & 13,4 & 16 & 16,4 & 15,8 & 7,9 \\
\hline $\begin{array}{l}\text { obtaining information on goods and } \\
\text { services not mentioned above }\end{array}$ & 16,2 & 17,5 & 16,8 & 21,3 & 20 & 18,4 & 2,2 \\
\hline number of households (thousands) & 4798,8 & 4948,7 & 4924 & 4900,1 & 4873.6 & 4844,2 & 45,4 \\
\hline $\begin{array}{l}\text { Part of households that have Internet } \\
\text { access at home, } \%\end{array}$ & 22,2 & 27,2 & 30,6 & 38,6 & 40,6 & 44,1 & 21,9 \\
\hline
\end{tabular}

Source:[9]

Today more than $80 \%$ of the population in Europe has access to the Internet. The reason why EU countries managed to achieve continuous coverage is the use of 
low-frequency bands (800-900 MHz) with technological neutrality. The Cabinet of Ministers of Ukraine has provided a background for the introduction of this technology in Ukraine. On October 29, 2019, the Cabinet of Ministers of Ukraine and mobile operators ensuring frequencies in the $900 \mathrm{MHz}$ band, signed a memorandum, which will provide $90 \%$ of the territory of Ukraine with high-speed 4G Internet. According to Mykhailo Fedorov, the Vice Prime Minister and Minister of Digital Transformation of Ukraine: 'One of the main tasks is providing 90\% of Ukrainian settlements, including the most remote ones, with high-quality high-speed Internet by 2022.' [26]

Conclusions and prospects. Based on the results of the study it is possible to conclude that the changes brought by the introduction and development of digital technologies in all areas of agricultural enterprises face a number of obstacles that can be overcome with the help of appropriate digital competencies.

Formation and development of digital competence of employees constitutes an integral part of marketing management in agricultural enterprises thus improving knowledge and skills of personnel when making managerial decisions, and providing competitive strengths and justification of enterprise development strategy.

\section{References:}

1. Association of Farmers and Private Landowners of Ukraine. Retrived from https://farmer.co.ua/ (Accessed 18 October 2020) (in Ukrainian)

2. Balabanova, L. V. (2004). Marketynhovyi menedzhment [Marketing management]. Kyiv. (in Ukrainian)

3. Balanovska, T.I., Havrysh, O.M., Wyrzykowska B. (2020) Formuvannja ta rozvytok cyfrovoji kompetentnosti pracivnykiv jak skladova antykryzovogho upravlinnja orghanizacijejuy [Formation and development of digital competence of employees as a component of anti-crisis management of the organization]. Economics. Management. Business, Vol. 1, No. 31. pp.97-106. Retrived from http://journals.dut.edu.ua/index.php/emb/article/view/2391 (in Ukrainian)

4. Bilovodska, O. A. (2010). Marketynhovyi menedzhment [Marketing management]. Kyiv. Retrived from https://essuir.sumdu.edu.ua/bitstreamdownload/123456789/38037/1/Bilovodska.pdf;jsessionid=D9C144721587D91A17B A65FC912ED3FF (in Ukrainian)

5. Unian (2020) The Internet boom in Ukraine: are we ready to jump online. Retrived from https://www.unian.ua/science/bum-internetu-v-ukrajini-chi-gotovimi-do-stribka-v-onlayn-novini-11039603.html (Accessed 5 October 2020) (in Ukrainian) 
6. Vedernikov, M.D., Chernushkina, O.O., Mantur-Chubata, O.S. (2018). Suchasni tekhnolohii upravlinnia personalom: kompetentsiinyi pidkhid [Modern technologies of personnel management: competent approach]. Naukovyi visnyk Uzhhorodskoho natsionalnoho universytetu. Seriia: Mizhnarodni ekonomichni vidnosyny ta svitove hospodarstvo. Vol. 19(1). pp.39-43. Retrived from http://nbuv.gov.ua/UJRN/Nvuumevcg_2018_19\%281\%2_11. (in Ukrainian)

7. Vojchak, A. V. (1998). Marketynhovyi menedzhment [Marketing management]. Kyiv. (in Ukrainian)

8. Dorada. Retrived from https://www.dorada.org.ua/ (Accessed 13 October 2020) (in Ukrainian)

9. Dostup domohospodarstv Ukrainy do internetu u 2019 rotsi (za danymy vybirkovoho obstezhennia umov zhyttia domohospodarstv Ukrainy): statystychnyi zbirnyk (2020). [Access households in Ukraine to the Internet in 2019 (according to a sample survey living conditions of Ukrainian households): statistical collection]. Retrived from https://ukrstat.org/uk/druk/publicat/kat_u/2020/zb/07/zb_dd_in19.pdf (in Ukrainian)

10. Information and analytical portal of agro-industrial complex. Retrived from https://agro.me.gov.ua/ua (Accessed 8 October 2020).

11. Kliuchovi kompetentnosti dlia navchannia vprodovzh zhyttia 2018 Tsyfrova kompetentnist [Key competences for lifelong learning 2018 - digital competence]. Retrived from http://dystosvita.blogspot.com/2018/01/2018.html

12. Komarnytskyi, I.M., Tsar, H.V. (2011). Teoretychni zasady formuvannia marketynhovoho menedzhmentu na pidpryiemstvi. [Theoretical principles of marketing management in enterprise]. Marketynh i menedzhment innovatsii. No. 3. pp. $110-116 . \quad$ Retrived

https://mmi.fem.sumdu.edu.ua/sites/default/files/mmi2011_3_2_110_116.pdf (in Ukrainian)

13. Agro Consulting Group. Retrived from http://agro-group.com.ua (Accessed 18 October 2020)

14. Kotler, Ph. (2007). Osnovy Marketynhu [Fundamentals of Marketing]. Moscow. Retrived from: http://htbiblio.yolasite.com/resources/12.11.15/Kotler_kratkiy_2007.pdf (in Russian)

15. Kuibida, V.S., Petroie, O.M., Fedulova, L.I., Androshchuk, H.O. (2019). Tsyfrovi kompetentsii yak umova formuvannia yakosti liudskoho kapitalu [Digital competences as a condition of quality formation human capital]. Kyiv. Retrived from http://academy.gov.ua/pages/dop/198/files/90a7d5c8-d10a-4f8f-89874d1077fdc8f6.pdf (in Ukrainian)

16. Leiko, S.V. (2013). Poniattia -kompetentsiiall ta -kompetentnistll: teoretychnyi analiz [The notions - competencell and -competencell: theoretical analysis]. The Pedagogical Process: Theory and Practice. No. 4. pp. 128-135. Retrived from http://nbuv.gov.ua/UJRN/pptp_2013_4_15. (in Ukrainian)

17. Agroexpert (2018). Mobile agricultural shop in the AgroUA mobile application. Retrived from: https://agroexpert.ua/mobilnii\%agrarnii\% 
magazin\%v\%mobilnomu\%dodatku\%agroua (Accessed 5 October 2020) (in Ukrainian)

18. Oleshko, A.A., Usatenko, A.O. (2019). Formuvannia ta rozvytok tsyfrovoi kompetentnosti personalu [Formation and development of digital competence of staff]. Investytsiyi: praktyka ta dosvid. No. 23. P. 16-19. Retrived from http://www.investplan.com.ua/pdf/23_2019/5.pdf (in Ukrainian)

19. Android.mobile-review (2020). Farewell PC, smartphone in a good way? Retrived from http://android.mobile-review.com/articles/66106/ (Accessed 5 October 2020) (in Ukrainian)

20. Pro zatverdzhennia Natsionalnoi ramky kvalifikatsii: Postanova Kabinetu Ministriv Ukrainy vid 23.11.2011. № 1341 [On Approval of the National Qualifications Framework: Resolution of the Cabinet of Ministers of Ukraine of November 13, $2011 \quad$ No. 1341]. Retrived from https://zakon.rada.gov.ua/laws/show/1341-2011-\%D0\%BF (in Ukrainian)

21. Pro skhvalennia Kontseptsii rozvytku tsyfrovoi ekonomiky ta suspilstva Ukrainy na 2018- 2020 roky ta zatverdzhennia planu zakhodiv shchodo yii realizatsii: Rozporiadzhennia Kabinetu Ministriv Ukrainy vid 17.01.2018 r. № 67-r [On approval of the Concept of development of the digital economy and society of Ukraine for 2018-2020 and approval of the plan of measures for its implementation: Order of the Cabinet of Ministers of Ukraine dated 17.01.2018 № 67-p]. Retrived from https://zakon.rada.gov.ua/laws/show/67-2018-\%D1\%80. (in Ukrainian)

22. Raiko, D.V., Lebedeva, L.E. (2015) Modelj upravlinnja marketynghom u systemi menedzhmentu promyslovogho pidpryjemstva [Marketing management model in the management system of an industrial enterprise]. Marketing and innovation management. Vol.1. pp. 107-123. Retrived from https://mmi.fem.sumdu.edu.ua/sites/default/files/mmi2015_1_107_123.pdf （in Ukrainian)

23. Rudenko, M.V. (2019) Tekhnologhiji cyfrovoji transformaciji siljsjkoghospodarsjkykh pidpryjemstv [Technologies of digital transformation of agricultural enterprises]. Agrosvit. Vol 23. pp. 8-18. (in Ukrainian)

24. Synychenko, A.V. (2016). Kompetentnisnyi pidkhid yak suchasna paradyhma upravlinnia personalom [Competence approach as a modern paradigm of personnel management]. Finance, accounting, banks. No 1 (21). 2016. pp. 288-294. Retrived from

http://irbisnbuv.gov.ua/cgibin/irbis_nbuv/cgiirbis_64.exe?C21COM=2\&I21DBN=UJRN\&P21 DBN=UJRN\&IMAGE_FILE_ DOWNLOAD=1\&Image_file_name=PDF/Fub_2016_1_32.pdf. (in Ukrainian)

25. Tkach, O.V, Balanyuk, I.F., Kopchak, Y.S., Balanyuk, S.I. (2016) Marketynghovyj menedzhment u dijaljnosti pidpryjemstv [Marketing management in the activities of enterprises]. Scientific Bulletin of Uzhhorod University. Vol. 1. pp. 292-296. (in Ukrainian) 
26. Cabinet of Ministers of Ukraine (2019). Government signs a memorandum that will ensure $4 \mathrm{G}$ coverage of $90 \%$ of Ukraine's territory. Retrived from https://www.kmu.gov.ua/news/uryad-pidpisav-memorandum-shchozabezpechit-pokrittya-4g-na-90-teritoriyi-ukrayini (Accessed 5 October 2020)

27. Fedulova, L.I. (2020). Rol tsyfrovykh kompetentsii u formuvanni informatsiinoi ekosystemy publichnoho upravlinnia [The role of digital competences in the formation of the public governance ecosystem]. Retrived from http://academy.gov.ua/pages/dop/

198/files/eb2ca970-be91-400ea34e8fdc0663763f.pptx (in Ukrainian)

28. Agricultural Consulting for friendly farming. Retrived from: https://www.farming.org.ua (Accessed 5 October 2020)

29. European Commission (2019). Council Recommendation on Key Competences for Lifelong Learning. Retrived from https://ec.europa.eu/education/education-in-the-eu/council-recommendation-onkeycompetences-for-lifelong-learning_en

30. K-press (2020). Marketing Analytic - program for marketing analysis. Retrived from http://www.k-press.ru/comp/2000/3/curs/curs.asp (Accessed 5 October 2020) (in Ukrainian)

31. Mirete, A.B., Maquilón, J.J., Mirete, L., Rodríguez, R.A. (2020). Digital Competence and University Teachers' Conceptions about Teaching. Sustainability. Vol. 12. No 1. pp. 1-13. Retrived from https://doi.org/10.3390/su12124842

32. PROD - buy and sell vegetables and fruits. Retrived from https://play.google.com/store/apps/details?id=com.prod\&hl=uk (Accessed 8 October 2020)

\section{Список використаних джерел:}

1. Асоціація фермерів та приватних землевласників України: вебсайт. URL: https://farmer.co.ua/ (дата звернення: 18.10.2020)

2. Балабанова Л.В. Маркетинговий менеджмент: навчальний посібник. Київ: Знання, 2004. 354 с.

3. Балановська Т. І., Гавриш О. М., Виржиковська Б. Формування та розвиток цифрової компетентності працівників як складова антикризового управління організацією. Економіка. Менеджмент. Бізнес. 2020. №1 (31). С. 97-106. URL: http://journals.dut.edu.ua/index.php/emb/article/view/2391

4. Біловодська О.А. Маркетинговий менеджмент: навчальний посібник. Київ: Знання, 2010. 332 с. URL: https://essuir.sumdu.edu.ua/bitstreamdownload/123456789/38037/1/Bilovodska.pdf;jsessionid=D9C144721587D91A17B A65FC912ED3FF

5. Бум інтернету в Україні: чи готові ми до стрибка в онлайн. Unian: вебсайт. URL: https://www.unian.ua/science/bum-internetu-v-ukrajini-chi-gotovimi-do-stribka-v-onlayn-novini-11039603.html (дата звернення: 05.10.2020)

6. Ведерніков М.Д., Чернушкіна О.О., Мантур-Чубата О.С. Сучасні технології управління персоналом: компетенційний підхід. Науковий вісник 
Ужгородського національного університету. Серія: Міжнародні економічні відносини та світове господарство. 2018. Вип. 19(1). C. 39-43. URL: http://nbuv.gov.ua/UJRN/Nvuumevcg_2018_19\%281\%29_11

7. Войчак А.В. Маркетинговий менеджмент: навчальний посібник. Київ: КНЕУ, 1998. 268 c.

8. Дорада: вебсайт. URL: https://www.dorada.org.ua/ (дата звернення: 13.10.2020)

9. Доступ домогосподарств України до інтернету у 2019 році (за даними вибіркового обстеження умов життя домогосподарств України): статистичний збірник. Державна служба статистики України. URL: https://ukrstat.org/uk/druk/publicat/kat_u/2020/zb/07/zb_dd_in19.pdf （дата звернення: 08.10.2020)

10. Інформаційно-аналітичний портал АПК: вебсайт. URL: https://agro.me.gov.ua/ua дата звернення: 08.10.2020).

11. Ключові компетентності для навчання впродовж життя 2018 Цифрова компетентність. Дистаниійне та змімане навчання інформатики: вебсайт. URL: http://dystosvita.blogspot.com/2018/01/2018.html

12. Комарницький I.M., Цар Г.В. Теоретичні засади формування маркетингового менеджменту на підприємстві. Маркетинг $i$ менеджмент інновацій. 2011. № 3. $\quad$ C. 110-116. URL: https://mmi.fem.sumdu.edu.ua/sites/default/files/mmi2011_3_2_110_116.pdf

13. Компанія Агро Консалтинг Груп : вебсайт. URL: http://agrogroup.com.ua (дата звернення: 18.10.2020)

14. Котлер Ф. Основы маркетинга: краткий курс / пер с англ. издательства «Прогресс». Москва: Издательский дом «Вильяме», 2007. 656 с. URL: http://htbiblio.yolasite.com/resources/12.11.15/Kotler_kratkiy_2007.pdf

15. Куйбіда В.С., Петроє О.М., Федулова Л.І., Андрощук Г.О. Цифрові компетенції як умова формування якості людського капіталу. Київ: НАДУ, 2019. 28 c. URL: http://academy.gov.ua/pages/dop/198/files/90a7d5c8-d10a-4f8f8987-4d1077fdc8f6.pdf

16. Лейко С. В. Поняття «компетенція» та «компетентність»: теоретичний аналіз. Педагогічний процес: теорія і практика. 2013. № 4 С. 128135. URL: http://nbuv.gov.ua/UJRN/pptp_2013_4_15

17. Мобільний аграрний магазин в мобільному додатку AgroUA : вебсайт. URL: https://agroexpert.ua/mobilnii-agrarnii-magazin-v-mobilnomu-dodatkuagroua/ (дата звернення: 05.10.2020)

18. Олешко А. А., Усатенко А. О. Формування та розвиток цифрової компетентності персоналу. Інвестиції: практика та досвід. 2019. № 23. С. 1619. URL: http://www.investplan.com.ua/pdf/23_2019/5.pdf

19. ПК прощай, смартфон в добру путь? Android.mobile-review: вебсайт. URL: http://android.mobile-review.com/articles/66106/ (дата звернення: 05.10.2020)

20. Про затвердження Національної рамки кваліфікацій: Постанова Кабінету Міністрів України від 23.11.2011 p. № 1341 // База даних «Законодавство України» / ВР України.

URL: 
21. Про схвалення Концепції розвитку цифрової економіки та суспільства України на 2018-2020 роки та затвердження плану заходів щодо ії реалізації: Розпорядження Кабінету Міністрів України від 17.01.2018 p. № 67-p. URL: https://zakon.rada.gov.ua/laws/show/67-2018-\%D1\%80 (дата звернення: 23.12.2019).

22. Райко Д.В., Лебедєва Л.Е. Модель управління маркетингом у системі менеджменту промислового підприємства. Маркетинг $i$ менеджмент інновачій. 2015. № 1. $\quad$ C. 107-123. URL: https://mmi.fem.sumdu.edu.ua/sites/default/files/mmi2015_1_107_123.pdf

23. Руденко М.В., Технології цифрової трансформації сільськогосподарських підприємств. Агросвіт. 2019. № 23. С. 8-18.

24. Синиченко А. В. Компетентнісний підхід як сучасна парадигма управління персоналом. Фінанси, облік, банки. № 1 (21). 2016. C. 288-294. URL: http://irbis-nbuv.gov.ua/cgi-bin/irbis_nbuv/cgiirbis_64.exe?C21COM=2\&I21DBN= UJRN\&P21DBN=UJRN\&IMAGE_FILE_DOWNLOAD=1\&Image_file_name=PDF /Fub_2016_1_32.pdf

25. Ткач О.В., Баланюк І.Ф., Копчак Ю.С., Баланюк С.I. Маркетинговий менеджмент у діяльності підприємств. Науковий вісник Ужгородського університету. Серія «Економіка». 2016. Вип. 1. С. 292-296.

26. Уряд підписав меморандум, що забезпечить покриття 4G на $90 \%$ території України. Кабінет Міністрів Украӥни: вебсайт. URL: https://www.kmu.gov.ua/news/uryad-pidpisav-memorandum-shcho-zabezpechitpokrittya-4g-na-90-teritoriyi-ukrayini (дата звернення: 05.10.2020)

27. Федулова Л.І. Роль цифрових компетенцій у формуванні інформаційної екосистеми публічного управління. URL: http://academy.gov.ua/pages/dop/198/files/eb2ca970-be91-400e-a34e8fdc0663763f.pptx

28. Agricultural Consulting for friendly farming: вебсайт. URL: https://www.farming.org.ua (дата звернення: 18.10.2020)

29. Council Recommendation on Key Competences for Lifelong Learning. European Commission: вебсайт. URL: https://ec.europa.eu/education/education-inthe-eu/council-recommendation-on-key-competences-for-lifelong-learning_en

30. Marketing Analytic - программа для маркетингового анализа : вебсайт. URL: http://www.k-press.ru/comp/2000/3/curs/curs.asp (дата звернення: 04.10.2020)

31. Mirete A.B., Maquilón J.J., Mirete L., Rodríguez R.A. Digital Competence and University Teachers' Conceptions about Teaching. Sustainability. 2020. Vol 12. No 1. pp. 1-13. URL: https://doi.org/10.3390/su12124842

32. PROD - купуй i продавай овочі та фрукти: вебсайт. URL https://play.google.com/store/apps/details?id=com.prod\&hl=uk (дата звернення: 08.10.2020) 


\title{
РОЛЬ ЦИФРОВОЇ КОМПЕТЕНТНОСТІ ПРАЦІВНИКІВ У МАРКЕТИНГОВОМУ МЕНЕДЖМЕНТІ СІЛЬСЬКОГОСПОДАРСЬКИХ ПІДПРИЕМСТВ
}

\author{
Т. Балановська, Б. Виржиковська, В. Восколупов
}

\begin{abstract}
Анотація. У статті розкрито роль цифрової компетентності працівників у маркетинговому менеджменті сільськогосподарських
\end{abstract} підприємств. Відмічено, що маркетинговий менеджмент $\epsilon$ одним 3 інновачійних підходів щзодо управління сільськогосподарським підприємством. Встановлено, що ефективність маркетингового менеджменту на всіх рівнях управління сільськогосподарським підприємством у великій мірі залежсть від всебічного розвитку прачівників, тому важливе значення слід приділяти не тільки професійним знанням фахівців зі спеціальності, а $і$ їхній здатності оперативно реагувати на вимоги ринку, вміти спілкуватися, брати відповідальність за результати діяльності, а також безперервно займатися самоосвітою. Зазначено, що постійна поява нових технологій, обладнання вимагає від праиівників відповідної иифрової компетентності.

Розкрито сутність ичиррової компетентності. Розглянуто основні складові використання ичиррової компетентності сільськогосподарськими товаровиробниками, які необхідні під час пошуку покупџів, постачальників, вивчення кон'юнктури ринку. Зважаючи на те, що використання сучасних цифрових технологій неможливе без підключення до інтернет-мережі, проаналізовано можливість доступу до інтернет-мережі сільського населення України. Відмічено, що формування й розвиток иифррової компетентності працівників $\epsilon$ невід'ємною складовою маркетингового менеджменту в сільськогосподарських підприємствах, щуо сприяє підвищенню рівня знань $i$ навичок персоналу при прийнятті управлінських рішень, забезпечує формування конкурентних переваг та обтрунтування стратегії розвитку підприємства.

Ключові слова: маркетинг, маркетинговий менеджмент, иифрова компетентність, маркетингові дослідження, сільськогосподарське підприємство. 